Tiimivalmentajan tueksi on kehitelty ja kehitellään erilaisia työvälineitä. Tuorein niistä on evankelisluterilaisen kirkon käyttöön tuotettu, mutta myös laajemmin tiimien rakentamiseen tarkoitettu Tiimin rakentajan Resurssireppu, jonka lehti esittelee ja arvioi ensi syksynä. Teknillinen korkeakoulu on vuorostaan kehittänyt seuraavassa kirjoituksessa esiteltävän Tiimivalmentaja Plus -välineistön, mistä tiimi voi räätälöidä kahdeksasta työvälineestä itselleen tarkoituksenmukaisimman kokonaisuuden. Aluksi Mari Ventä kuvaa tiimityöskentelyyn liittyviä odotuksia ja pettymyksiä.

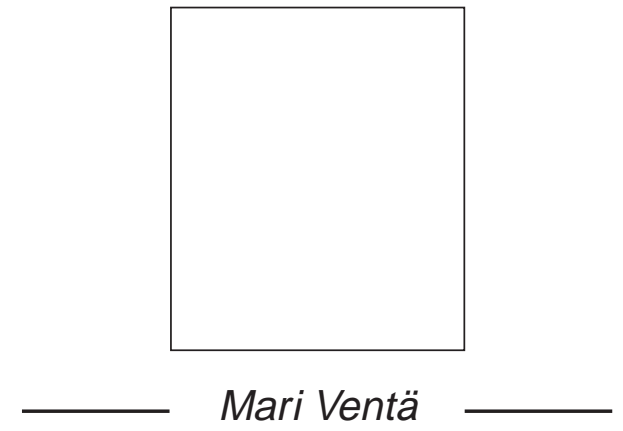

\title{
Tiimivalmentaja Plus -välineistö tiimien kehittämisen tukena
}

M onissa yrityksissä on siirrytty 1990-Iuvulla tiimityöhön, mutta liian nopeasti käyttöönotettu tiimiorganisaatio ei ole aina suinkaan saavuttanut sille asetettuja tavoitteita (Gordon 1992, 64). Jos tiimien jäseniltä on odotettu monitaitoisuutta, itseohjautuvuutta ja vastuunottamista, mutta uusien asioiden oppimiseen ei ole annettu tarpeeksi aikaa, tiimeissä on saatettu turhautua. Uusilla valtuuksilla ja vastuulla sekä monitaitoisuuden vaatimuksilla kuormitetut tiimiläiset eivät enää välttämättä tunne hallitsevansa o maa työtään (Z enger, ym. 1994).

Y ksi suurimmista syistä tiimityöskentelyn epäonnistumiseen on rajauksien väljyys. Tiimillä tulee olla selvä käsitys valtuuksistaan, asiakkaistaan, tehtävistään tiimissä ja asemastaan organisaatiossa (H irschhorn, ym. 1992). Tiimin jäsenet sitoutuvat sitä enemmän tiimin toimin- taan, mitä selkeämpi kuva heillä on tehtävistään ja merkityksestään tiimille (VinokularK aplan 1995).

Toinen tyypillinen tiimimäisen työskentelyn epäonnistumisen syy on sellainen harhaluulo monitaitoisuudesta, että tiimissä kaikkien tulisi tehdä kaikkea. Dunphy ja Bryant (1996) toteavat tekemiensä tapaustutkimusten pohjalta, etä tiimin jäsenten monitaitaisuutta tulœ pyrkiä lisäämään vain tiettyn rajaan asti. M onien tehtävien kompetenssivaatimukset ovat niin suuria, etteivät tiimin resurssit riitä kaikkien tiimin jäsenten kouluttamiseen kyseisiin tehtäviin. Dunphyn ja Briantin mukaan tiimin jäsenten monitaitoisuutta lisättäessä on myös syytä ottaa huomioon yksilöiden henkilökohtaiset kyvyt ja asenteet. E rilaisista osaamisalueista on 
kaikkèn eniten hyötyä silloin, kun niitä hyödynnetään tiimissä toisiaan täydentävästi ( $K$ atzenbach \& Smith 1993, 30).

\section{Tiimityön tunnuspiirteet}

$\mathrm{H}$ ankaluuksista, takapakeista ja sivupoluista huolimatta tiimimäisellä työskentelyllä on vankat etunsa: harkiten ja pitkän ajanjakson aikana ohjattuna tiimipohjainen organisaatio voi tulla muita organisaatiomuotoja tuottavammaksi ja tiimiläisten työskentelymotivaatiota lisääväksi vaihtoehdoksi. (N ahavandi \& Aranda 1994, 58; Z enger, ym. 1994, 25). O nnistuakseen tiimityön tulee kuitenkin rakentua aiemmista organisaatiomalleista poikkeaville aineksille eli erilaisten näkemysten ja arvostusten myöntämiselle, tiimien kokoonpanon muuttumiskyvylle sekä tiimiläisten valtuuttamiselle eli vallan siirtämiselle työntekijätasolle ( $\mathrm{N}$ ahavandi \& Aranda 1994). Myös yrityksen johdon tulee sopeutua uuteen tilanteeseen. Vallan siirtäminen alaspäin ja organisaation madaltuminen vaikuttavat väistämättä totuttuihin valtasuhteisiin.

Tiimimäisessä työskentelyssä on selvät tunnuspiirteet, jotka erottavat sen muista ryhmämäisen työskentelyn muodoista: tiimin jäsenet pyrkivät sitoutumaan yhteisiin tavoitteisiin ja toimintamalleihin, olemaan monitaitoisia sekä kantamaan yksilö- ja yhteisvastuuta tuloksista. Tiiminä työskentely ei ole helppoa eikä tiimiksi kehittyminen tapahdu hetkessä. Tiimille onkin tyypillistä, että toiminta kehittyy erilaisten vaiheiden kautta kohti yhä moniulotteisempaa tiimimäisen työskentelyn tasoa. (K atzenbach \& Smith 1993.)

\section{Tiimivalmentaja tiimin tukena}

Tiimin toiminnan ratkaisevana tukijana toimii usein tiimivalmentaja. Tiimivalmentaja-käsite on saanut eri yhteyksissä erilaisia merkityksiä, mutta tässä artikkelissa sillä tarkoitetaan henkilöä, jolla on muita suurempi vastuu tiimin tai organisaatiossa sovellettavan tiimityön toimivuudesta, tuloksellisuudesta, käynnistämisestä ja kehittämisestä. Tiimivalmentajana voi toimia nimetty tiimin vetäjä tai johtaja, yksikön funktionaalinen esimies, organisaation sisäinen kehittäjä tai ulkopuolinen konsultti.

\section{Käytännölliset apuvälineet tiimin kehittymisen tueksi}

Tiimimäisen työskentelyn ja tiimin kehittymisen ongelmiin on pyritty etsimään ratkaisuja Teknillisen korkeakoulun tuotantotalouden osaston Tiimimittarit-projektissa. Projektissa on kehitetty Tiimivalmentaja Plus -työvälineistö, joka tarjoaa tiimivalmentajille apuvälineitä tiimien toiminnan ohjaamiseen. Tiimi voi räätälöidä kahdeksasta työvälineestä tiimivalmentajan opastuksella mahdollisimman tarkoituksenmukaisen kokonaisuuden, joka ohjaa sitä miettimään tavoitteitaan, mittareitaan, hyvinvointiaan ja toimivuuttaan sekä tapoja antaa ja saada palautetta toiminnastaan.

Työvälineistön käytön perustana on tiimin tavoitteiden määrittely. $K$ un tiimin jäsenillä on yhteinen käsitys toimintansa suunnasta, he voivat aloittaa toimintaa kuvaavien mittareiden suunnittelemisen. Pelkkä tavoitteiden ja mittareiden määrittely ei kuitenkaan yksin tue tiimin kehittymistä, vaan työvälineiden käytön päätavoite on auttaa tiimejä kehittymään päivittäistyöskentelyssään. Tällöin keskeiseksi nousee mittareiden antaman palautteen hyödyntäminen. Työvälineistössä tiimille tarjotaan erilaisia tapoja konkretisoida kehitysajatukset todellisiksi toimintaa kehittäviksi muutoksiksi. (A altonen, ym. 1996.)

\section{Työvälineistön taustalla olevat oppimiskäsitykset}

K onstruktivistisen oppimisnäkemyksen mukaan oppimiseen liittyy kiinteästi tiedon käyttöyhteys. Tiedolla itsessään ei ole juurikaan merkitystä, jos oppija ei osaa liittää sitä sopivaan käyttötarkoitukseen. Tämä ongelma kohdataan esimerkiksi opittaessa uutta tietoa koulutustilaisuuksissa. K oulutustilaisuuksiin osallistuneiden on usein vaikea siirtää käyttötarkoituksestaan irrallisena esitettyä tietoa oman työnsä, esimerkiksi tiimitoiminnan, kehittämiseen ( $\mathrm{K}$ auppi 
$1989,110)$. Monet organisaatiot ovatkin todenneet, että vain 10-15 prosenttia yksilön työhön liittyvästä uudesta tiedosta opitaan koulutuksessa. 85-90 prosenttia opitaan työn ohella. (Raybould 1995, 2.)

Tiimivalmentaja Plus -työvälineistössä on pyritty ratkaisemaan oppimisen siirtovaikutusongelma muuttamalla painopistettä opettamisesta oppimiseen. Työvälineistö on suunniteltu siten, että oppiminen tapahtuu konstruktivistisen oppimisnäkemyksen mukaan mahdollisimman pitkälle tiimin omassa työympäristössä työn ohella ja oppimistilanteissa ratkaistaan omaan työhön liittyviä ongelmia. Esimerkiksi tiimioppimisesta ei esitetä pelkästään teoreettisia näkemyksiä, vaan työvälineistöstä löytyy o hjelma ja tarkka opastus tiimin osaamisprofiilin luomiseksi. O saamisprofiilin avulla tiimin jäsenet voivat ohjata omaa kehittymistään siten, että se palvelee sekä tiimin intressejä että henkilökohtaisia oppimistarpeita. O saamisprofiilia on käytetty muun muassa tiimin työnkierron koordinoinnin apuvälineenä.

K onstruktivistisen oppimisnäkemyksen lisäksi työvälineistössä korostuu näkemys uudistavasta oppimisesta. Pelkkä vanhojen toimintatapojen kehittäminen ei riitä, vaan oppijoiden tulisi irtautua kokonaan vanhoista käsityksistään ja kriittisen reflektion kautta pyrkiä sisäistämään työtoimintansa aivan uudella tavalla (Senge 1990, 53; Kolb, ym. 1991, 59). Tiimimäiseen työskentelyyn sovellettuna uudistava oppiminen tarkoittaa sitä, että tiimin jäsenet eivät muokkaa vanhoja tottumuksiaan tiimitoimintaan sopiviksi, vaan pyrkivät löytämään aivan uusia, juuri tiimityöskentelyyn sopivia työskenteIyn muotoja. Uusia muotoja on Tiimivalmentaja Plus -työvälineiden käyttäjätiimeissä haettu muun muassa $\mathrm{H}$ enki-keskustelumenetelmällä, jonka ohjeistus löytyy työvälineistöstä. H enki tukee tiimin uudistavaa oppimista siten, että se ohjaa tiimiä keskustelemaan monipuolisesti tärkeistä, joskus vaikeistakin, tiimityön osa-alueista, kuten vastuusta, johtamisesta ja tiedonvälityksestä. K eskustelussa nousseita ideoita on vastuutettu ja niiden toteuttamista koordinoitu työvälineistön Tiimi-idealomakkeella. Vaikka idea vastuuttamisesta ja aikataulutuksesta ei ole uusi, monet tiimit ovat todenneet, että ilman muistiinpantuja vastuuhenkilöitä ja aikatauluja vain harvat ideat tulevat toteutetuiksi.

K ehitettäessä tiimin oppimista tukevia apuvälineitä lähtökohtana on koko tiimin yhteinen oppiminen yksilökeskeisen oppimisnäkemyksen sijasta. N äkökulma pitää sisällään kuitenkin dilemman: Vaikka kyseessä on koko tiimin oppiminen ja kehittyminen, oppiminen tapahtuu aina yksittäisten tiimin jäsenten oppimisen kautta. Tiimin oppimiseen vaikuttavat siten tiimis-

\section{Profiilimatriisi}

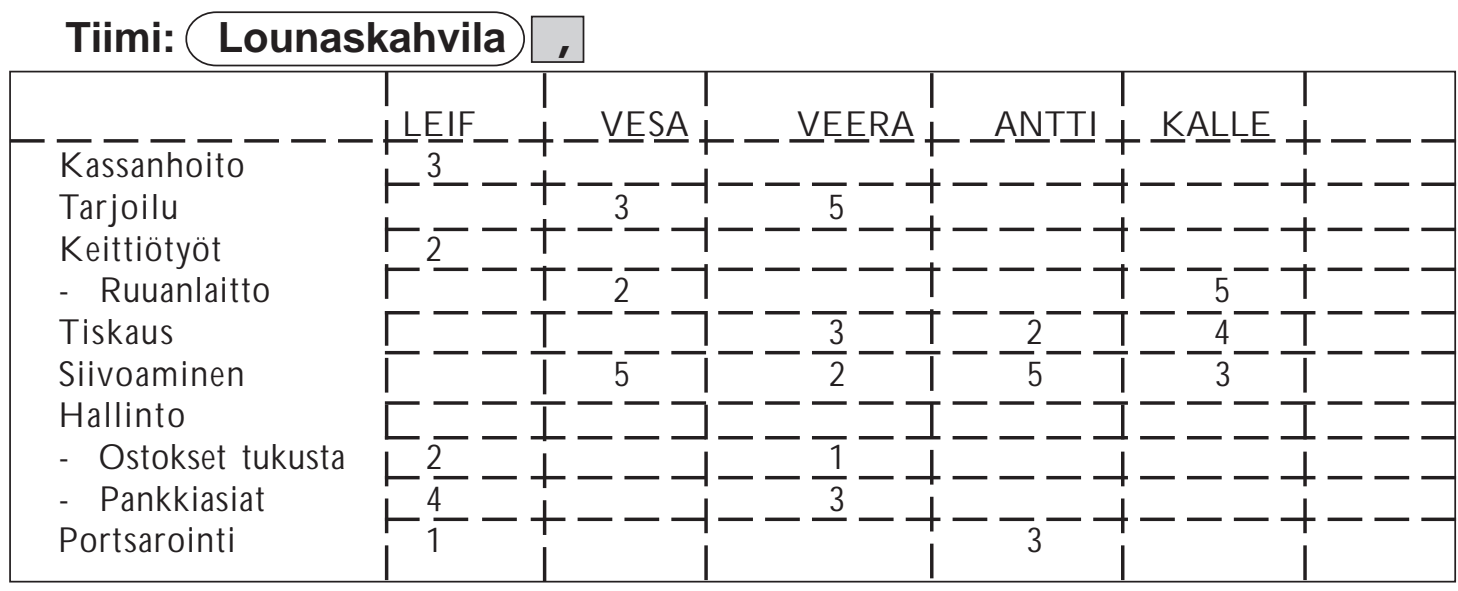

Tiimivalmentaja Plus -työvälineistö on tiimien tietotekninen apuvälineistö. Esimerkki sen osaamisprofiliohjelmasta. 0 saamisprofiilia on käytetty $\mathrm{mm}$. tiimin työnkierron koordinoinnin apuvälineenä. 
sä olevien yksilöiden arvot, uskomukset, normit, tiedot ja käyttäytyminen ( $D$ echant, $M$ arsick \& K asl 1993). Toisaalta tiimi voi vaikuttaa yksittäisen tiimin jäsenen arvomaailmaan ja oppimisen viitekehykseen. Tiimivalmentaja Plus -työvälineistössä on useita työvälineitä, jotka ohjaavat tiimiläisten avoimeen keskusteIuun erilaisista aiheista. Esimerkiksi K ompassityövälineen ohjaamat tiimin tavoitekeskustelut ovat osoittautuneet hyviksi tilaisuuksiksi omien arvojen ja mielipiteiden julkituomiseen sekä toisaalta tiimin yhteisen näkemyksen luomiseen.

\section{Tavoitteena sitoutuminen ja osaamisen leviäminen}

Tiimivalmentaja Plus -työvälineistössä on tavoitteena syventää tiimiläisten sitoutumista. Jos tiimiläiset eivät ole valmiita kehittämään ja tarvittaessa muuttamaan toimintaansa, työvälineiden läpikäynti muuttuu helposti puuhasteluksi, jolla ei ole vaikutusta työn tuottavuuteen eikä tiimin to imivuuteen. Sitoutumisen ja motivaation lähteenä työvälineistössä on osallistuva työtapa. Tiimivalmentaja Plus on suunniteltu käytettäväksi tiimivalmentajan ja tiimin jäsenten yhteistyönä. Tiimiläisten vastuu työvälineistön tarkoituksenmukaisesta käytöstä on suuri, ja valmentajan päätehtävänä on tukea tiimiläisiä niiden toimintamallien avulla, joita työvälineisiin on sisällytetty.

Y ksilöt ja tiimit kehittävät paljon sellaista tietoa, josta olisi hyötyä koko organisaatiolle, mutta organisaatiolta puuttuu tehokkaat tavat levittää tietoa ja edistää koko organisaation oppimista. K ilpailijoitaan nopeammin organisaation edellytyksenä kuitenkin on, että jokainen ottaa vastuun tiedon levittämisestä, jolloin tieto leviää mahdollisimman nopeasti kaikkien sitä tarvitsevien organisaation jäsenten käyttöön. (Raybould 1995; D rucker 1988)

K äytännössä koko organisaation oppimista on edistänyt muun muassa Tiimivalmentaja Plus työvälineistön asentaminen organisaation sisäiseen tietoverkkoon. $\mathrm{N}$ äin kaikilla tiimeillä on ollut mahdollisuus hyödyntää työvälineistöä ja jakaa uusia toimintatapoja. E räässä organisaa- tiossa tiimien laatimat oppimisprofiilit yhdistettiin, jolloin saatiin osastoittainen kuva siitä, millaista osaamista on kussakin tiimissä ja miten tiimien välistä yhteistyötä voitaisiin lisätä.

\section{Tietotekniikka: väline, ei itsetarkoitus}

Tiimivalmentaja Plus -työvälineistö on tietoteknisessä muodossa, mutta tietotekniikan tarkoituksena on toimia ainoastaan tiedon levittämisen ja työstämisen välineenä. Periaatteessa tietoa voitaisiin esittää myös muillakin tavoin, mutta tietotekniikan on katsottu tuovan työvälineisiin sellaista lisäarvoa mm. levitettävyydessä ja organisaation yhteisten toimintatapojen luomisessa, mitä ei olisi muilla keinoilla mahdollista saavuttaa.

O ngelmana tietoteknisessä muodossa olevissa työvälineissä on se, että käyttäjät saattavat kuvitella tekniikan hallinnan tuovan mukanaan myös sisällön hallintaa, jolloin työvälineen sisältöön tutustuminen jää vajaavaiseksi. Pahimmassa tapauksessa työvälineitä käytetään täysin epätarkoituksenmukaisesti (Ilomäki 1996, 7). Esimerkiksi eräässä tiimissä motivaatio ei riittänyt omien tavoitteiden määrittelyyn, jolloin tiimiläiset kopioivat toisen tiimin tavoitemäärittelyt ja nimesivät ne suoraan omiksi tavoitteikseen. Tiimivalmentaja huomasi tempun yllättävän samanlaisen sisällön lisäksi siitä, että kopioiduksi oli tullut myös toisen tiimin nimi! Vastaavissa tilanteissa tiimivalmentajan tärkeä tehtävä on motivoida tiimiläisiä ja painottaa sitä, että työvälineistö on tiimin omaa kehittymistä, ei ketään ulkopuolista tahoa varten.

Tiimivalmentaja Plus -työvälineistön käyttäjäorganisaatioilla oletetaan olevan tietyt kehittämisvalmiudet ja sisältöalueen hallintaa jo entuudestaan. Työvälineistö perustuu pitkälti sille oletukselle, että käyttäjäorganisaatioissa on tiimin kehittymisen tukena toimivia tiimivalmentajia, jotka ottavat vastuun työvälineistön sisältämän osaamisen levittämisestä. Sellaisiin organisaatioihin, jotka ovat tottuneet käyttämään ulkopuolisia resursseja toimintansa kehittämiseen, työvälineistön itseohjautuva käyt- 
täminen voi osoittautua liian suureksi vaatimukseksi. E simerkiksi jotkut käyttäjistä ovat aluksi olleet pettyneitä työvälineistön tarjoamiin apuvälineisiin tiimin omien mittarien laatimiseksi. Paremmin asiaan perehdyttyään he ovat kuitenkin huomanneet, että lopultakaan tiimeille ei voi tarjota valmiita mittareita, vaan jokaisen tiimin on itse työstettävä juuri omaa toimintaansa tukevat mittarit, mutta työvälineistö tuo mittarien laatimista helpottavia työvälineitä.

\section{Taustalla tutkimusta ja testausta}

Tiimivalmentaja Plus -tuotetta on nyt kehitetty $2^{1 / 2}$ vuotta. Tuotekehitykselle on ollut eduksi se, että jo tuotteen ensimmäisistä versioista lähtien tuotetta on päästy testaamaan Tiimimittarit-projektin yhteistyöyrityksissä. $\mathrm{N}$ äin tuote on muovautunut sekä teoreettisten mallien että käytännön tiimityön kokemusten pohjalta. Toukokuun aikana Tiimivalmentaja Plus -työvälineistöstä julkaistaan 2.1-versio, jossa on parannettu $\mathrm{mm}$. tuotteen rakennetta ja toimivuutta organisaation sisäisessä verkossa.

Tuotetta on levitetty intensiivisesti syksystä 1997 asti. Tähän mennessä se on otettu käyttöön usean pankki- ja vakuutusalan yrityksen kymmenissä tiimeissä. E nsimmäisiä käyttökokemuksia on saatu myös julkisen sektorin toimistotyötä tekevistä tiimeistä sekä tuotannon tiimeistä. Tuotannon tiimeillä on ilmennyt aivan uusia haasteita työvälineen käytössä, sillä esimerkiksi tiimin jäsenten fyysinen sijoittuminen eri paikkakunnille on vaikeuttanut työvälineistön käytön vaatimien yhteisten palaverien pitoa.

Tiimivalmentaja Plus -työvälineistön kehittäminen poikkeaa ainoastaan konsultatiivisiin tarkoituksiin suunnatusta tuotekehityksestä siten, että toimintaan liittyy vahvasti jatko-opinnäytteisiin tähtäävä tutkimus. Tiimimittarit-projektin projektipäällikkö Antti K oivula on valmistellut väitöskirjaa asiantuntijapalvelujen tuotteistamisesta, jolloin tapausesimerkkinä on Tiimivalmentaja Plus -tuotteen kehittämisprosessi. O ma lisensiaatintyöhön tähtäävä tutkimukseni keskittyy Tiimivalmentaja Plus -työvälineis- tön käyttöönottoon. Työn tarkoituksena on tuoda uutta tietoa tietotuotteen käyttöönottoon liittyvistä tekijöistä.

\section{Lähteg}

AALTONEN, P., KOIVULA, A., PANKAKOSKI, M., TEI. KARI, V. \& VENTÄ, M. (1996) Tiimistä toimeen K uinka kirkastat tiimin tavoitteet ja luot mittariston sekä palautejärjestelmän. HUT Industrial Managemant and Work and Organizational Psychology. Working $\mathrm{Pa}-$ per No 3 .

DECHANT, K., MARSICK, V. J. \& KASL, E. (1993) Towards a model of team learning. Studies in Continuing Education, 15 (1), 1-14.

DRUCKER, P. (1988) The Coming of the N ew Organization. Harward Business Review. January-February 1988.

DUNPHY, D. \& BRYANT, B. (1996) Teams: Panaceas or Prescriptions for Improved Performance? Human Relations. 1996 May, 49:5, 677-699.

GORDON, J. (1992) Work Teams: How Far Have They Come? Training, O ctober, 59-65.

HIRSCHHORN, L. \& GILMORE, T. (1992) The New Boundaries of the "Boundaryless" Company. Harward Business Review. May-June 1992, 70(3), 104-115.

ILO M ÄKI, L. (1996) O ppimisen taitojen tukeminen tietokoneavusteisessa opetusohjelmassa. Teoksessa: Tietotekniikka osaamisen tukena. HUT Industrial Management and Work and Organizational Psychology. Working Paper 4, 7-14.

KATZENBACH, J. \& SMITH, D. (1993) Tiimit ja tuloksekas yritys. Jyväskylä: G ummerus K irjapaino $O \mathrm{y}$.

K OLB, D. A., RUBIN, I. M. \& OSLAND, J. (1991) Organizational Behavior: an Experimental Approach. Englewood Cliffs, N ew Jersey: Prentice-H all, Inc.

NAHAVANDI, A. \& ARANDA, E. (1994) Restructuring Teams for the Re-engineered 0 rganization. A cademy of $M$ anagement Executive, 8 (4), 58-68.

PERK IN S, D. N. (1991) Technology Meets Constructivism: Do They Make a Marriage? Educational Technology, 31 (5), 18-23.

RAYBOULD, B. (1995) Performance Support Engineering: An Emerging D evelopment M ethodology for E nabling $O$ rganizational Learning. Performance I mprovement Q uarterly. Special Issue on Electronic Performance Support Systems. Special E ditor: G loria G rey. 8: 1. Learning System Institute Florida State U niversity.

RAUSTE-VON WRIGHT, M.\& VON WRIGHT, J. (1994) O ppiminen ja koulutus. Juva: WSOY.

SENGE, P. (1990) The Fifth D iscipline, The Art and Practise of the Learning O rganization. N ewYork: D oubleday.

VIN OK ULAR-K APLAN, D. (1995) Treatment Teams That Work (and Those That Don't): An Application of Hackman's Group Effectiveness Model to Interdiciplinary Teams in Psychiatric Hospitals. Journal of Applied Behavioral Science, 31 (3), 303-327.

ZENGER, J., MUSSELWHITE, E., HURSON, K.\& PERRIN , C. (1994) Leading Teams - Mastering the N ew Role. Business $\mathrm{O}$ ne Irwin, Homewood, Illinois. 